\title{
Mekanisme Survival Selama Pandemi Covid-19: Belajar Dari Pengalaman Perempuan Single Mother di Perdesaaan Madura
}

\author{
${ }^{1}$ Deviana Mayasari \\ Kandidat Doktoral Sosiologi, FISIP, Universitas Brawijaya \\ deviana mayasari@yahoo.com \\ ${ }^{2}$ Hoiril Sabariman \\ Alumni Magister Ilmu Sosial, FISIP, Universitas Brawijaya
}

\section{Keywords:}

Covid-19 Pandemic; Women; Challenges;

Survival;

Pandemi Covid-19;

Perempuan;

Tantangan;

Kelangsungan Hidup

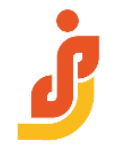

BRAWIJAYA JOURNAL of SOCIAL SCIENCE

Vol. 1, No. 1,2021

DOI:

https://doi.org/10. 21776/ub.bjss.2021 .001 .01 .6

Submitted:2021-12-03 Accepted:2021-12-07

\section{Abstract}

The impact of the Covid-19 pandemic adds to the burden for single mothers. In addition to performing two functions at once, the pandemic forces them to survive difficult situations. This article describes the challenges facing singlemother as well as survival mechanisms during pandemics by phenomenological studies through direct observation and in-depth interviews conducted on single mothers in Ponteh Village. Data showed some of the challenges single-mother faced during the pandemic. First, there is an increase in double burden. One of the additional tasks for a single mother is the increasing burden of taking care of households needs due to their children's schooling from home. Second, the decrease in income for household needs resulted from the government's mobility restriction policy. Third, the stereotyping of women (widows) that leads to social pressures. Survival mechanisms carried out by single mother during the pandemic are as follows. First, fostering optimism and taking care of each other. Second, using social relationships. Third, downsizing through reduced consumption and food substitutes, and fourth, diversifying and intensifying their jobs. This article therefore adds to the understanding that single mother women are no longer considered women who are unable to take care of their families when in fact they are able to overcome helplessness and difficult challenges.

\section{Abstrak}

Dampak pandemi Covid-19 menambah beban bagi perempuan single mother. Selain menjalankan dua fungsi sekaligus, pandemi memaksa mereka untuk dapat bertahan dalam situasi sulit. Artikel ini menjelaskan tantangan yang dihadapi perempuan single mother serta mekanisme survival selama pandemi. Studi fenomenologi digunakan, melalui pengamatan langsung dan wawancara mendalam dilakukan terhadap perempuan single motherdi Desa Ponteh. Data menunjukkan, beberapa tantangan yang dihadapi perempuan single mother 
selama pandemi. Pertama, meningkatnya beban ganda. Salah satu penambahan tugas yaitu meningkatnya beban mengurus rumah tangga akibat bersekolahnya anak-anak dari rumah (School From Home). Kedua, menurunnya pendapatan untuk kebutuhan rumah tangga yang diakibatkan kebijakan pembatasan mobilitas masyarakat oleh pemerintah. Ketiga, stereotip perempuan (janda) dalam masyarakat yang mengakibatkan tekanan sosial. Mekanisme survival yang dilakukan perempuan single mother selama pandemi antara lain; pertama, menumbuhkan optimisme dan saling menjaga. Kedua, memanfaatkan relasi sosial. Ketiga, berhemat melalui pengurangan konsumsi dan bahan pengganti pangan, dan keempat, melakukan diversifikasi dan intensifikasi pekerjaan. Kontribusi keilmuan artikel ini adalah menambah pemahaman bahwa perempuan single mother tidak lagi dianggap sebagai perempuan yang tidak mampu mengurusi keluarga. Bahkan, di tengah ketidakberdayaan dan tantangan sulit, mereka mampu mengatasinya.

\section{Pendahuluan}

Kondisi persebaran Covid-19 hampir menyangkut semua negara di dunia. Pola persebaran virus yang berpindah dengan mudah dan cepat, World Health Organization (WHO) menghimbau bahkan memaksa semua negara-negara di dunia guna memberlakukan kebijakan physical distancing (Harirah Ms \& Rizaldi, 2020). Physical distancing dalam konteks Indonesia memodifikasinya dengan nama Pembatasan Sosial Berskala Besar (PSBB) hingga Pemberlakuan Pembatasan Kegiatan Masyarakat (PPKM). Pembatasan sosial ini diberlakukan per wilayah sesuai dengan keparahan persebaran Covid-19 yang ditentukan oleh pemerintah pusat melalui Kementerian Kesehatan (KEMENKES). Kebijakan PPKM secara umum diberlakukan dengan membatasi kerumunan masyarakat, seperti menutup tempat-tempat wisata/hiburan dan perbelanjaan, mengurangi jam kerja pasar, libur sekolah baik negeri atau swasta, serta menerapkan kebijakan bekerja di rumah (WFH) bagi kantor-kantor yang bukan termasuk sektor penting bagi keberlangsungan masyarakat. Berbagai pembatasan lainnya yang sesuai dengan konteks masyarakat diperlukan guna memutus penularan Covid-19. Namun, penerapan social and physical distancing (menjaga jarak aman antar individu dan menghindari kerumunan) bukan pekerjaan yang mudah. Hal ini karena memaksa mengubah perilaku sosial masyarakat supaya terbiasa dengan kondisi new normal (tatanan sosial baru) (Muhyiddin, 2020).

Pembatasan sosial akibat pandemi tersebut berdampak dalam semua bidang, mulai dari sosial, ekonomi, kesehatan, kesejahteraan, yang menghadapkan masyarakat pada risiko nyata. Pemberlakuan pembatasan sosial berakibat hilangnya pekerjaan secara luas khususnya masyarakat kelas menengah ke bawah. Akhirnya masyarakat terpuruk pada kondisi ketidakberdayaan dalam memenuhi kebutuhan keluarganya. Aspek ekonomi dalam hal ini sulitnya pemenuhan kebutuhan pokok, sampai dengan memburuknya relasi sosial yang sempat dirasakan oleh sebagian partisipan. Salah satunya adalah kaum perempuan (Andayani, 2021). 
Kaum perempuan adalah salah satu kelompok yang paling terkena dampak dari pandemi Covid-19. Berdasarkan hasil survei menjelaskan bahwa perempuan yang bekerja informal memiliki ketidakjelasan secara penghasilan di masa pandemi Covid-19. Sehingga mendorong terjadinya kekerasan ekonomi, yang berdampak terhadap terjadinya kekerasan fisik, psikologis dan seksual. Hasil penelitian menunjukkan bahwa pandemi Covid-19 memberikan dampak terhadap ketahanan ekonomi kehidupan keluarga pekerja perempuan sektor informal. Hal ini ditandai dengan kondisi pekerja perempuan sektor informal yang kehilangan pekerjaan, pemberhentian kerja selama pandemi dan menurunnya pendapatan yang dihasilkan selama pandemi. Selain itu, kondisi krisis akibat pandemi juga menjadi pemicu konflik dalam keluarga seperti hubungan pekerja perempuan sektor informal dan suaminya yang mengalami pertentangan (Nursakina, 2021). Kaum Perempuan merupakan salah satu kelompok sosial yang paling rentan ketika terjadi suatu bencana (Handayani, 2019). Perempuan di tengah pandemi mengalami permasalahan yang luar biasa. Kebanyakan mereka memilih hanya sebagai buruh sampingan yang bisa dikerjakan dari rumah dengan tetap mengawasi anak mereka (Purnawati, 2021).

Namun, beberapa literatur menjelaskan tentang beberapa perempuan mampu bertahan dari dampak yang ditimbulkan oleh pandemi Covid 19. Seperti penjelasan Sari \& Suranto (2021), Nursakina (2021), Erowati et al (202), Hasanah (2021). Sari \& Suranto (2021) memaparkan bahwa perempuan pedagang sayur keliling sebagai tulang punggung ekonomi keluarga, memainkan peran yang sangat besar dalam perekonomian keluarga dengan menjadi pencari nafkah utama yang mampu mendukung dan meningkatkan pendapatan rumah tangga keluarga (Sari \& Suranto, 2021). Nursakina (2021) menjelaskan pekerja perempuan sektor informal berperan menggantikan suami selama pandemi demi memenuhi kebutuhan keluarga dan bertahan pada kondisi pandemi yang mengancam keberlangsungan kehidupan keluarganya. Pekerja perempuan sektor informal beradaptasi dengan kondisi tersebut seperti menghemat pengeluaran dengan cara mengkonsumsi makanan yang lebih murah serta melakukan usaha-usaha produktif demi menambah penghasilan menjadi tukang cuci pakaian, buruh dan menjual makanan. Pekerja perempuan sektor informal sebagai perempuan dan istri dalam keluarga memiliki peran tradisi sebagai pengurus rumah tangga dan dianggap sebagai pencari nafkah kedua dalam keluarga mengalami pergeseran peran (Nursakina, 2021).

Bahkan, perempuan di tengah pandemi Covid-19 tidak sebatas menjadi korban yang paling rentan. Justru beberapa perempuan menjadi garda depan dalam penanggulangan pandemi. Terdapat beberapa perempuan yang menjadi dokter dan perawat berkerja di garis depan melawan pandemi. Perempuan bekerja secara individu atau terorganisir, baik pemerintah atau organisasi sosial masyarakat (swasta) (Erowati et al., 2020). Selain dalam bidang kesehatan, perempuan memiliki peran penting para pemimpin di komunitas akar rumput selama pandemi Covid-19. Perempuan sebagai salah satu pemimpin di komunitas menjadi salah satu faktor penting yang dapat mendorong adanya perubahan ekonomi dan mendekatkan akses program pemerintah bagi penerima manfaat yang tepat sasaran di masa pandemi (Hasanah, 2021). Hasil dari 
pemberdayaan perempuan melalui komunitas akar rumput ini tidak hanya dirasakan oleh perempuan tapi juga orang tua, suami, anak-anak, serta beberapa kelompok rentan lainnya yang ada di desa. komunitas akar rumput ini mampu meningkatkan kepercayaan diri perempuan guna mengahadapi dampak pandemi. Selain itu, perempuan dapat meningkatkan partisipasi, akses, kontrol dan manfaat program perlindungan sosial di masa pandemi Covid-19 (Hasanah, 2021).

Selama masa pandemi, perempuan single motherdi Desa Ponteh telah melakukan peran ganda dan semakin mempersulit mereka. Selain bekerja sebagai ibu rumah tangga seperti menyapu, mencuci, memasak, merawat anak, mencari nafkah, fungsi sosial dalam masyarakat. selama pandemi, perempuan single mother bertambah bebannya menjadi guru bagi anaknya yang belajar dari rumah. Berdasarkan uraian latar belakang di atas dari berbagai literatur dan fenomena, perlu untuk dikaji lebih mendalam mengenai tantangan, serta strategi dalam menghadapi dampak Covid-19. Sehingga tujuan artikel ini adalah memahami dan menganalisis dinamika perempuan single mother, tantangan yang dihadapi, serta mekanisme survival selama pandemi Covid-19 di Desa Ponteh Kecamatan Galis Kabupaten Pamekasan Madura. Artikel ini diharapkan menjadi panduan mengenai berbagai upaya yang dilakukan perempuan single mother berdasarkan pengalaman selama pandemi. Sehingga perempuan single mother tidak lagi dianggap sebagai perempuan yang tidak mampu mengurusi keluarga. Bahkan, di tengah ketidakberdayaan dan tantangan sulit, mereka mampu mengatasinya.

\section{Metode Penelitian}

Penelitian ini menggunakan metode kualitatif dengan pendekatan fenomenologi. Pendekatan fenomenologi dihubungkan pada pemahaman kehidupan keseharian, intersubjektif (dunia kehidupan) dari realitas sosial yang diteliti, yaitu perempuan single mother. Pengungkapan makna atau konsep pengalaman perempuan dalam situasi yang dialami. Penggunaan pendekatan fenomenologi didukung oleh beberapa fakta; pertama, data penelitian ini merupakan fakta atau realitas yang terlihat, termasuk pola prilaku keseharian perempuan single mother dalam menghadapi dampak pandemi Covid-19. Perilaku saat berinteraksi dengan keluarga, teman kerja, dan masyarakat. perempuan sebagai aktor yang diteliti merupakan sebuah fenomena dari yang tersembunyi pada "diri" perempuan. Perlu pemahaman dan pemaknaan lebih lanjut dari realitas yang diteliti. Kedua, penelitian ini mengungkap pengalaman perempuan single mother yang menjadi salah satu kelompok rentan ketika ada musibah. Ketiga, pengalaman yang dilakukan perempuan dapat membentuk makna pada perempuan single mother di perdesaan Madura. Sehingga menghasilkan pemahaman yang mendalam dan komprehensif tentang kondisi perempuan single mother dalam menghadapi pandemi Covid-19 (Creswell, 2007).

Informan dalam penelitian ini ditentukan berdasarkan teknik purposive sampling. Dalam teknik purposive sampling, yang menjadi syarat utama adalah kriteria informan harus sesuai dengan tujuan penelitian, serta memahami dan menguasai permasalahan yang diteliti (Sugiyono, 2016). Mengacu pada tujuan penelitian, terdapat beberapa 
kriteria informan; pertama, informan merupakan perempuan tidak memiliki suami (meninggal/bercerai) yang sudah memiliki tanggungan anak. Kedua, perempuan memiliki pekerjaan tetap. Sehingga ditetapkan tiga informan dengan perbedaan latar belakang pekerjaan. Ibu Lia bekerja sebagai pedagang sayur. Ibu Luluk sebagai penjaga warung makan, dan Ibu Didin yang bekerja sebagai buruh tani.

Penelitian ini bersumber dari data primer dan data sekunder. Data primer didapat observasi, wawancara mendalam (in-depth interview). Pengumpulan data dilakukan dengan kondisi alami, yang lebih banyak observasi partisipasi. Wawancara dilakukan dengan mendatangi rumah informan, yang sebelumnya mengadakan kesepakatan waktu. Langkah ini dilakukan supaya tidak mengganggu aktivitas informan penelitian ketika bekerja atau sedang berkumpul dengan keluarga. Sedangkan data sekunder didapat dari dokumen-dokumen pendukung yang tidak diperoleh secara langsung, misal dari artikel atau penelitian yang sesuai dengan topik yang diangkat. Data yang dikumpulkan, kemudian diolah dan dianalisis menggunakan teknik analisis data interaktif Miles dan Huberman, yang membandingkan hasil penelitian dengan temuan penelitian yang terdahulu (Miles et al., 2014). Proses analisis dilakukan dengan mendeskripsikan data-data yang telah terkumpul dalam bentuk teks yang diperluas melalui deskripsi. Analisis terdiri dari tiga aliran sekaligus meliputi reduksi data (data reduction), penyajian data (data display) serta Penarikan kesimpulan dan verifikasi (conclusion drawing/ verification). Setelah semua data selesai dianalisis, kemudian dilakukan teknik triangulasi; 1) sumber, dan 2) metode (Creswell, 2007).

\section{Hasil dan Pembahasan}

\subsection{Dinamika Perempuan Single Motherdi Perdesaaan Madura}

Perempuan single mother di Madura sulit untuk dapat mengembangkan potensi dirinya. Konteks lokal masyarakat Madura masih memandang perempuan sebagai individu yang tidak mampu, termarjinalkan, dan sebatas mengurusi bagian rumah tangga. Jadi perempuan harus dilindungi oleh kaum laki-laki. Berdasarkan data yang diperoleh, dapat diketahui dinamika perempuan single motherdi perdesaan Madura dari latar belakang pendidikan, pekerjaan, status ekonomi, status menjanda yang dipilihnya. Pendidikan terakhir perempuan single mother rata-rata sebagian besar Sekolah Rakyat (setingkat SD), ada yang lulusan SMP dan kejar paket (setara SMA). Penyebab para perempuan single mother tidak mengenyam pendidikan tinggi karena tekanan sosial, misal ada ungkapan yang sering diungkapkan masyarakat Madura "perempuan tidak perlu pendidikan tinggi, meskipun menyelesaikan pendidikan tinggi nanti juga akan kembali mengurusi mengurusi dapur, rumah tangga, dan suami”. Hal senada dijelaskan oleh Ibu Lia yang bekerja sebagai pedagang sayur:

"saya dulu tidak sempat melanjutkan pendidikan karena waktu itu dinikahkan beberapa waktu setelah lulus SD. sempat mau sekolah, tapi tidak dapat izin dari orang tua. katanya biarkan adek saya yang laki-laki saja yang melanjutkan sekolah" (Wawancara dengan Ibu Lia, n.d). 
Selain karena stereotip yang melekat pada perempuan, biaya pendidikan menjadi salah satu penghalang untuk melanjutkan pendidikan. Hal ini didukung oleh orang tua yang memilih menyekolahkan anak laki-laki daripada perempuan. Berdasarkan profil Desa Ponteh (2020) kaum perempuan telah banyak bekerja di sektor produktif. Antara lain; berdagang sayuran, menjaga toko, pembantu rumah tangga, usaha warung makan, menjahit, membuat kue atau jajanan lokal. Perempuan yang memilih hidup sendiri (single mother) memenuhi kebutuhan keluarga dengan bekerja sesuai latar belakang yang dimiliki. Seperti penjelasan Ibu Luluk sebagai penjaga warung makan:

"saya sejak kecil dulu sudah diajak orang tua untuk bekerja di warung makan. menjadi pengalaman hingga saat ini ketika saya bekerja. saat bekerja masih ada hal-hal yang tidak enak yang dibicarakan tetangga kepada saya, apalagi janda. kayaknya serba salah dalam masyarakat"(Wawancara dengan Ibu Luluk, n.d).

Keterlibatan perempuan single motherdalam perekonomian produktif, mengubah pandangan anggota masyarakat lain terhadap perempuan. Saat perempuan single mother memiliki cukup tabungan, mereka memilih membuka toko kelontong yang dijaga orang tua di rumah. Seperti yang dijelaskan oleh Ibu Didin yang bekerja sebagai buruh tani:

"kalau ada uang lebih, saya kadang menabung. dengan berjualan di rumah. ya gimana lagi saya sebenarnya pengen kerja di rumah saja. tapi sudah menjadi tanggung jawab saya sebagai orang tua tunggal untuk mencari nafkah" (Wawancara dengan Ibu Didin, n.d).

Para perempuan single mother menyadari bahwa jika dapat memilih, kerja di sektor domestik merawat anak di rumah. Namun, pilihan menjadi tulang punggung keluarga dengan tanggung jawab mereka sebagai mencari nafkah utama. Sehingga ketika sebatas mengerjakan kegiatan rumah tangga, memasak, menyapu, mencuci mereka merasa tidak nyaman jika hanya menjalankan tugas domestik. Perempuan single mother di Desa Ponteh didapatkan bahwa peran ganda yang dijalankan dalam keseharian merasa tidak terbebani. Segala hal yang mereka lakukan adalah merupakan akibat memilih dengan menjadi ibu rumah tangga tunggal. Perempuan single mother yang bekerja, memiliki daya tawar dalam masyarakat. Bagi mereka, dengan bekerja meminimalkan terjadinya bahan pembicaraan masyarakat. Kaum perempuan mengadakan berbagai kegiatan, misal; arisan setiap minggu. Arisan ada berupa arisan uang dan arisan barang. selain arisan, berkumpulan perempuan adalah kegiatan muslimat biasanya diisi dengan shalawatan, dzikir bersama, dan membaca ya-sin bersama-sama. Arisan menjadi tabungan untuk kebutuhan masa depan, misal; membuka usaha, membangun rumah, dan membeli kendaraan baru (Sabariman, 2019).

\subsection{Tantangan yang Dihadapi Perempuan Single Mother Selama Pandemi Covid-19}

Selama pandemi, posisi perempuan menjadi salah satu kelompok yang mengalami kerentanan. Khususnya ibu rumah tangga tunggal (janda). Perempuan single mother di 
Desa Ponteh selama ini telah menjalankan fungsi domestik dan fungsi publik secara bersamaan. Seperti penjelasan Ibu Lia bekerja sebagai pedagang sayur:

"sebelum berangkat membeli barang dagangan ke pasar, saya menyiapkan kebutuhan anak untuk sekolah dan berbagai kebutuhan lainnya. Selesai berjualan sayur keliling di kampung sebelah, pulangnya langsung beres-beres rumah seperti menyapu. Sehingga sore dan malam biasanya berkumpul dengan anak dan orang tua"(Wawancara dengan Ibu Lia, n.d).

Diperjelas oleh pemaparan Ibu Luluk sebagai penjaga warung makan:

"sebelum berangkat kerja ke sawah atau tegal milik warga, saya harus menyiapkan berbagai kebutuhan orang tua dan anak. Maklum orang tua saya sudah sepuh, sedang anak saya sekolah SMP. Setelah shalat subuh biasanya saya langsung memasak untuk sarapan, setelah itu menyapu rumah dan halaman. Saya berangkat kerja jam 06.00 dari rumah, sampai pulang lagi sekitar menjelang shalat magrib” (Wawancara dengan Ibu Luluk, n.d).

Perempuan single mother di Desa Ponteh menjalankan dua peran sekaligus, yaitu fungsi domestik dan fungsi publik. Fungsi domestik berupa kegiatan rumah tangga yang oleh masyarakat dianggap kurang produktif seperti menyapu, mencuci, memasak, merawat anak. Sedangkan fungsi publik berupa mencari nafkah, fungsi sosial dalam masyarakat. dalam keseharian, fungsi domestik dan fungsi publik lazim dilaksanakan oleh perempuan single mother. Beberapa kondisi peran ini tidak berjalan sesuai yang diharapkan, misal adanya kerugian bagi perempuan yang menjalankan usaha. Hal yang sama bagi perempuan yang bekerja sebagai penjaga warung dan buruh tani. Perempuan single mother dalam menghadapi dampak pandemi Covid-19 menjadi lebih sulit dalam memenuhi kebutuhan keluarga. Selain beban ganda, beberapa tantangan yang dihadapi perempuan single mother selama pandemi covid-19 di perdesaan Madura. Pertama, meningkatnya beban ganda perempuan single mother. Sebelum pandemi, perempuan telah terbiasa memiliki beban ganda. Salah satu penambahan tugas yaitu meningkatnya beban mengurus rumah tangga akibat sekolah dari rumah (School From Home).

Setelah pemerintah menetapkan tidak diadakan kegiatan belajar mengajar secara tatap muka, maka murid akan melakukan pembelajaran jarak jauh (daring). Bagi perempuan single motherini menjadi tantangan tersendiri, karena mereka harus menjadi guru di rumah untuk memantau kegiatan belajar anaknya. Terkadang, saat tidak diawasi anak-anak tidak mengerjakan perintah dari gurunya, malah bermain game online. Kondisi ini dianggap berat oleh perempuan, karena mereka harus berpikir ulang dengan kebiasaan baru tersebut. Kedua, menurunnya pendapatan untuk kebutuhan rumah tangga. Kebijakan pembatasan mobilitas masyarakat oleh pemerintah berupa Pembatasan Sosial Berskala Besar (PSBB) dan Pemberlakuan Pembatasan Kegiatan Masyarakat (PPKM) mengakibatkan tempat keramaian seperti pasar mengalami pembatasan. Selain pasar, rumah makan juga menurun yang diakibatkan pembatasan sosial. Seperti penjelasan Ibu Lia: 
"serba capek juga corona ini, pasar jadi sepi sehingga saya sulit mendapatkan bahan jualan. Masyarakat juga takut bertemu dengan saya Karena takut kena corona katanya"(Wawancara dengan Ibu Lia, n.d).

Hal yang sama dijelaskan oleh Ibu Didin yang bekerja sebagai buruh tani:

"saat corona melanda, pengunjung orang-orang yang mau makan di warung ini turun drastis. Akibatnya pendapatan saya juga menurun. Hal ini karena saya dibayar dengan sistem persentase, sebesar 10\% dari hasil penjualan"(Wawancara dengan Ibu Didin, n.d).

Pembatasan ruang gerak dan interaksi masyarakat menjadi tantangan bagi informan di masa pandemi. Kegiatan pekerjaan perempuan single mother bertumpu pada gerak sosial masyarakat. Sehingga pendapatan penjual sayur keliling mengalami penurunan. Tantangan terakhir yang dihadapi perempuan single mother selama pandemi Covid-19, Ketiga. Stereotip perempuan (janda) dalam masyarakat yang berikat pada tekanan sosial. Lazimnya di perdesaan Madura menjadi perempuan single mother akan dijadikan bahan pembicaraan warga. Seperti yang diutarakan Ibu Luluk:

"serba salah memang kalo sama masyarakat. saya sebagai janda kerja di warung makan selalu jadi pembicaraan warga. Saat corona seperti ini juga dibicarakan, karena tanpa bekerja bisa dapat uang”(Wawancara dengan Ibu Luluk, n.d).

Para perempuan single mother di Desa Ponteh memiliki berbagai tantangan yang harus dihadapi dalam menghadapi pandemi Covid-19. Tiga poin utama tantangan yang dihadapi oleh perempuan single mother di perdesaan Madura, Pertama, meningkatnya beban ganda perempuan single mother. Kedua, menurunnya pendapatan untuk kebutuhan rumah tangga. Ketiga. Stereotip perempuan (janda) dalam masyarakat yang terikat pada tekanan sosial. Salah satu tantangan yang dihadapi perempuan single mother didukung oleh studi yang dilakukan Juita et al (2020) tentang kendala yang dihadapi perempuan di masa pandemi. Perempuan yang tidak memiliki suami (janda) menjadi tulang punggung keluarga. Kendala yang dihadapi oleh perempuan bekerja dalam tingkat persaingan, kemampuan, transportasi, dan faktor pendidikan. Pendapatan yang tidak menentu, memaksa perempuan agar dapat memenuhi kebutuhan sehari-hari (Juita et al., 2020). Lebih lanjut, sependapat dengan pemikiran Handayani (2019) bahwa kaum perempuan merupakan salah satu kelompok sosial yang paling rentan ketika terjadi suatu bencana.

\subsection{Mekanisme Survival Perempuan Single Mother Selama Pandemi Covid-19}

Dalam menghadapi kondisi sulit akibat dampak dari pandemi, ada beberapa respon yang dilakukan oleh para perempuan single mother di perdesaan Madura. Terdapat empat hal utama yang mereka lakukan guna menghadapi kondisi sulit selama pandemi; optimisme dan saling menjaga, memanfaatkan relasi sosial, berhemat melalui pengurangan konsumsi dan bahan pengganti pangan, melakukan diversifikasi dan intensifikasi pekerjaan atau tanaman untuk konsumsi rumah tangga di pekarangan rumah. Berlandaskan pada operasionalisasi dari kerangka konseptual, berikut empat poin penting dalam temuan penelitian tentang mekanisme survival perempuan single 
mother selama pandemi Covid-19; pertama, menumbuhkan optimisme dan saling menjaga. Terdapat beberapa peran tambahan yang dilakukan perempuan single mother selama pandemi. Selain peran mencari nafkah dan mengurusi pekerjaan rumah tangga, peran sebagai guru akibat pembelajaran dari rumah. Perempuan dihadapkan pada pilihan sulit, di satu sisi harus meningkatkan pendapatan dengan bekerja di luar rumah, sisi sebaliknya memaksa di rumah karena harus mengawasi anak yang sedang belajar jarak jauh (daring). Seperti penjelasan Ibu Lia, seorang ibu rumah tangga tunggal yang memiliki anak kelas 5 SD;

"anak saya masih kelas 5 SD. corona ini membuat saya bingung antara bekerja dan menjag anak yang sekolah lewat HP. saya yakin, Allah segera mengangkat covid ini, sehingga kita tidak takut lagi untuk beraktifitas seperti semula. tapi meski ada aturan dari permerintah saya harus tetap mencari nafkah. paling tidak kita saling menjaga untuk tetap merasa baik-baik saja di tengah pandemi" (Wawancara dengan Ibu Lia, n.d).

Meskipun di tengah kondisi sulit akibat dampak pandemi, perempuan single mother tetap memiliki optimisme dalam menjalani kehidupan. Dari konteks wawancara dengan Ibu Lia, optimisme muncul karena rasa tanggung jawab sebagai pencari nafkah utama dalam keluarga. Selain itu, nilai-nilai religius muncul sebagai pegangan hidup. Kedua, memanfaatkan relasi sosial. Jaringan atau relasi sosial memiliki peran penting bagi perempuan single motherdalam penelitian ini. Ibu Luluk, seorang ibu rumah tangga tunggal, menyampaikan bahwa persaingan buruh tani semakin meningkat. Hal ini merupakan dampak dari pembatasan sosial, sehingga banyak pekerja di luar pertanian yang terkena PHK masuk juga dalam bidang pertanian. Namun, karena relasi sosial yang telah terbentuk lama antar buruh tani, mereka tetap menggunakan tenaga yang ada di kelompoknya. Seperti penjelasan Ibu Didin:

"saat ada permintaan tenaga kerja untuk tenaga pertanian, kami memiliki kelompok tersendiri. meskipun ada banyak yang mendaftar untuk diajak kerja, kami tetap mengajak yang ada dalam kelompok utama. kadang saat tidak ada panggilan pekerjaan pertanian kami juga ikut proyekan (bangunan selokan, jalan dII)"(Wawancara dengan Ibu Didin, n.d).

Ketiga. berhemat melalui pengurangan konsumsi dan bahan pengganti pangan. Seperti pemaparan Ibu Lia sebagai pedagang sayur keliling:

"selama musim corona ini pendapatan saya mengalami penurunan. jadi secara tidak langsung harus mengurangi pada pengeluaran untuk makanan. contoh, biasanya 50rb cukup lima hari, kini dijadikan seminggu. cara dengan mengubah kebiasaan lama, contoh mengurangi membeli daging ayam dengan mengganti dengan tahu dan tempe, mengganti beras dengan jagung dan umbi-umbian, memanfaatkan sayur di pekarangan rumah"(Wawancara dengan Ibu Lia, n.d).

Perempuan single mother yang bekerja sebagai penjual sayur keliling tidak meninggalkan kewajiban menjaga anak dan mengelola rumah tangga. Meskipun 
pandemi telah memangkas pendapatannya, mereka mampu bertahan dengan strategi berhemat. Mekanisme survival yang dilakukan perempuan single mother dalam menghadapi pandemi-19. Keempat, melakukan diversifikasi dan intensifikasi pendapatan. Seperti penjelasan Ibu Luluk sebagai penjaga warung makan:

"saat warung makan sepi oleh pengunjung saya biasanya kerja serabutan. kadang mencuci pakaian milik tetangga yang membutuhkan, menjadi buruh tani, bahkan menanami pekarangan yang dapat dikonsumsi sendiri seperti sayur, cabe, tomat" (Wawancara dengan Ibu Luluk, n.d).

Mekanisme survival yang dilakukan perempuan single mother selama pandemi Covid-19 melalui, menumbuhkan optimisme dan saling menjaga, memanfaatkan relasi sosial, berhemat melalui pengurangan konsumsi dan bahan pengganti pangan, dan melakukan diversifikasi dan intensifikasi pekerjaan. Fenomena ini didukung oleh studi yang dilakukan Andari (2020), bahwa dalam menghadapi pandemi, keluarga miskin berhemat pengeluaran konsumsi keluarga. Selain itu, mengganti makanan utama seperti beras dengan bahan yang lebih murah, misal jagung dan umbi-umbian. Keluarga melakukan berbagai upaya tersebut supaya dapat bertahan hidup dalam menghadapi pandemi (Andari, 2020). Selain itu, strategi adaptasi yang dilakukan oleh keluarga dalam menghadapi kehidupan sosial baru melalui: diversifikasi, intensifikasi, pemanfaatan jaringan sosial, serta memobilisasi anggota keluarga (Hamzah \& Nurdin, 2021). Lebih jauh, perempuan bekerja sebagai pedagang di masa pandemi mampu membantu menopang ekonomi keluarga. Perempuan mampu menjalankan dua fungsi sekaligus yaitu peran rumah tangga dan sebagai pencari nafkah (Juita et al., 2020).

Konteks situasi perempuan single motherselama masa pandemi Covid -19, mereka mampu beradaptasi dan melakukan mekanisme bertahan hidup dengan melakukan berbagai upaya. Sejalan dengan pemaparan Parson dalam kerangka konsep AGIL yaitu adaptasi, dalam kondisi darurat pandemi Covid-19 sistem sosial yang ada harus mampu menjawab tantangan yang muncul dari luar lingkungan masyarakat. Sistem sosial yang berkembang dalam masyarakat harus menyesuaikan diri dengan kebutuhannya (Ritzer et al., 2010). Sementara Armitage dan Plummer (2010) menjelaskan kemampuan adaptasi individu atau masyarakat merupakan berbagai upaya penyesuaian memiliki perbedaan berdasarkan kemampuan individu serta modal sosial yang dimilikinya. Kemampuan adaptasi merupakan berbagai upaya, siap siaga guna merespon perubahan hambatan dari internal atau eksternal dari lingkungan masyarakat (Plummer \& Armitage, 2010). Mekanisme survival yang dilakukan perempuan single motherselama pandemi Covid-19 berupa menumbuhkan optimisme dan saling menjaga, memanfaatkan relasi sosial, berhemat melalui pengurangan konsumsi dan bahan pengganti pangan, dan melakukan diversifikasi dan intensifikasi pekerjaan. perempuan single mother dapat beradaptasi dengan mengatasi masalah yang berasal dari lingkungan, dengan melakukan penyesuaian terhadap norma-norma, serta menyesuaikan diri dengan situasi yang berubah akibat pandemi (Soekanto, 2009).

\section{Kesimpulan}


Di tengah pandemi Covid-19 saat ini, perempuan single mother di Desa Ponteh telah melakukan peran ganda dan semakin mempersulit mereka. Selain bekerja sebagai ibu rumah tangga seperti menyapu, mencuci, memasak, merawat anak, mencari nafkah, fungsi sosial dalam masyarakat. Selama pandemi, perempuan single motherbertambah bebannya menjadi guru bagi anaknya yang belajar dari rumah, serta pembatasan sosial yang menghambat dalam memenuhi kebutuhan keluarga. Beberapa tantangan yang dihadapi perempuan single mother selama pandemi Covid-19 di perdesaan Madura. Pertama, meningkatnya beban ganda perempuan single mother. Sebelum pandemi, perempuan telah terbiasa memiliki beban ganda. Salah satu penambahan tugas yaitu meningkatnya beban mengurus rumah tangga akibat sekolah dari rumah (School From Home). Kedua, menurunnya pendapatan untuk kebutuhan rumah tangga yang diakibatkan kebijakan pembatasan mobilitas masyarakat oleh pemerintah berupa Pembatasan Sosial Berskala Besar (PSBB) dan Pemberlakuan Pembatasan Kegiatan Masyarakat (PPKM). Ketiga. Stereotip perempuan (janda) dalam masyarakat yang terikat oleh tekanan sosial. Lazimnya di perdesaan Madura menjadi perempuan single mother menjadi pembicaraan warga.

Menanggapi berbagai tantangan yang diakibatkan oleh dampak pandemi, perempuan single mother melakukan beberapa cara untuk mempertahankan hidup. Mekanisme survival yang dilakukan perempuan single motherselama pandemi Covid-19 antara lain; pertama, menumbuhkan optimisme dan saling menjaga dalam keluarga. Kedua, memanfaatkan relasi sosial yang sudah ada sebelumnya. Ketiga, melakukan penghematan melalui pengurangan konsumsi dan bahan pengganti pangan, seperti beras diganti jagung, daging diganti tahu dan tempe. Keempat, melakukan diversifikasi dan intensifikasi pekerjaan. mekanisme yang dilakukan perempuan single mother. Perempuan single mother tidak lagi dianggap sebagai perempuan yang tidak mampu mengurusi keluarga. Bahkan, di tengah ketidakberdayaan dan tantangan sulit, mereka mampu mengatasinya.

\section{Daftar Pustaka}

Andari, S. (2020). Mekanisme Survival Warga Miskin Perkotaan Terdampak Penyebaran Covid-19. Jurnal Penelitian Kesejahteraan Sosial, 19(3), Article 3. https://doi.org/10.31105/jpks.v19i3.2104

Andayani, T. R. (2021). Sumber informasi serta dampak penerapan pembatasan sosial dan fisik pada masa pandemi COVID-19: Studi eksploratif di Indonesia. Jurnal Psikologi Sosial, 19(2), 11-121. https://doi.org/10.7454/jps.2021.13

Creswell, J. W. (2007). Qualitative inquiry and research method: Choosing among five approaches. Sage Publications.

Erowati, D., Prasetyo, K. B., Astuty, S., \& Anggraeni, T. (2020). Peran Organisasi Perempuan dalam Penguatan Social Capital Melawan Pandemi Covid-19 (Studi pada Gerakan Kampanye Sosial Persit Kartika Chandra Kirana XXXIX 
Kabupaten Pati Jawa Tengah). Umbara, 5(1), 30-41. https://doi.org/10.24198/umbara.v5i1.28056

Hamzah, A., \& Nurdin, H. S. (2021). Strategi Adaptasi Nelayan Selama Pandemi Covid19 di Pelabuhan Perikanan Nusantara Karangantu. Akuatika Indonesia, 6(1), 25-30. https://doi.org/10.24198/jaki.v6i1.30685

Handayani, B. L. (2019). Memperkuat Modal Sosial Perempuan Dalam Menghadapi Bencana. Journal of Urban Sociology, 1(1), 16-34. https://doi.org/10.30742/jus.v1i1.561

Harirah Ms, Z., \& Rizaldi, A. (2020). Merespon Nalar Kebijakan Negara Dalam Menangani Pandemi Covid 19 di Indonesia. Jurnal Ekonomi Dan Kebijakan Publik Indonesia, 71), 36-53. https://doi.org/10.24815/ekapi.v7i1.17370

Hasanah, I. (2021). Menghadang Pemiskinan Perempuan di Masa Pandemi Covid-19 (Pengalaman Sekolah Perempuan Gresik Dalam Memperkuat Akses Perempuan Miskin Terhadap Program Perlindungan Sosial Di Masa Pandemi Covid-19). Prosiding Seminar Nasional Penanggulangan Kemiskinan, 1(1), Article

https://conference.trunojoyo.ac.id/pub/index.php/semnaspk/article/view/51 Juita, F., Mas`ad, M., \& Arif, A. (2020). Peran Perempuan Pedagang Sayur Keliling Dalam Menopang Ekonomi Keluarga Pada Masa Pandemi COVID-19 di Kelurahan Pagesangan Kecamatan Mataram Kota Mataram. CIVICUS: Pendidikan-Penelitian-Pengabdian Pendidikan Pancasila dan Kewarganegaraan, 8(2), 100-107. https://doi.org/10.31764/civicus.v8i2.2916

Miles, M. B., Huberman, A. M., \& Saldana, J. (2014). Qualitative Data Analysis, A Methods Sourcebook (3rd ed.). Sage Publications. Terjemahan Tjetjep Rohindi Rohidi, UI-Press.

Muhyiddin, M. (2020). Covid-19, New Normal, dan Perencanaan Pembangunan di Indonesia. Jurnal Perencanaan Pembangunan: The Indonesian Journal of Development Planning, 4(2), 240-252. https://doi.org/10.36574/jpp.v4i2.118

Nursakina, N. (2021). Pekerja Perempuan Pada Sektor Informal Menghadapi Pandemi Covid-19 di Kota Makassar [Other, Universitas Hasanuddin]. http://repository.unhas.ac.id/id/eprint/3640/

Plummer, R., \& Armitage, D. (2010). Integrating Perspectives on Adaptive Capacity and Environmental Governance. In D. Armitage \& R. Plummer (Eds.), Adaptive Capacity and Environmental Governance (pp. 1-19). Springer. https://doi.org/10.1007/978-3-642-12194-4_1

Purnawati, L. (2021). Pemahaman Beban Ganda Perempuan di Tengah Pandemi. Translitera: Jurnal Kajian Komunikasi dan Studi Media, 10(2), 27-36. https://doi.org/10.35457/translitera.v10i2.1702

Ritzer, G., Douglas, J., \& Goodman. (2010). Teori Sosilogi Modern. Kencana.

Sabariman, H. (2019). Perempuan Pekerja (Status Dan Peran Pekerja Perempuan Penjaga Warung Makan Kurnia). Jurnal Analisa Sosiologi, 8(2), Article 2. https://jurnal.uns.ac.id/jas/article/view/34084 
Sari, A. A., \& Suranto. (2021). Pedagang Sayur Keliling Perempuan Sebagai Tulang Punggung Ekonomi Keluarga Di Desa Pondok Karangrejo Kabupaten Grobogan [S1, Universitas Muhammadiyah Surakarta]. https://doi.org/10/LAMPIRAN.pdf

Soekanto, S. (2009). Peranan Sosiologi Suatu Pengantar. Rajawali Pers.

Sugiyono. (2016). Metode Penelitian Kuantitatif Kualitatif dan R\&D. Alfabeta. 